\title{
AOR
}

Selected Papers of \#AoIR2020: The $21^{\text {st }}$ Annual Conference of the Association of Internet Researchers Virtual Event / 27-31 October 2020

\section{MORAL ECONOMIES OF OPEN DATA PLATFORMS AND SMART CITIES}

\author{
Ryan Burns \\ University of Calgary \\ Preston Welker \\ University of Calgary
}

Municipal open data platforms are currently caught in a range of tensions. They rely on an unspecified subject to analyze the data, and yet are surrounded by discourses of "empowerment" and "transparency" (Barns 2016; Beer 2018; Dunbar-Hester 2020). They are often most beneficial when approached with data science skills, yet often entail unremunerated digital labor (Burns and Andrucki 2020; Irani 2015; Schrock 2016). And they are often engaged by organizations tacking some variant of "for Social Good" onto their mandate - the Canada-wide organization Data for Good being a key example.

To date, research has generated important insights into the political economies of data and platforms that highlight the ways they produce, mediate, circulate, and accumulate surplus and exchange value. From "data colonialism" (Couldry and Mejias 2019) to "platform capitalism" (Srnicek 2017), this research tends to focus on material conditions under which political economies function; that is to say, for example, exchange is conceived as a trade of commodity for money, and labor is conceived as work for payment (Benkler 2006; Graham, Hjorth, and Lehdonvirta 2017).

Less attention has been devoted to understanding the ways moral values and sentiments are deployed to attract the digital volunteered labor subtending municipal open data platform usage. This omission disregards the discursive work of the lexicon surrounding municipal open data platforms. For instance, the term "open" itself promotes a slippage between multiple meanings, such that proponents may deploy the term for ambiguous social contributions (Yu and Robinson 2011). Others have called into question the similar claims that open data platforms necessarily lead to "accountability" and "transparency" (Burns and Wark 2019; Civil Beat 2013; Kitchin 2014). Those who mobilize these moral economies are deeply situated within capitalist Suggested Citation (APA): Burns, R, P Welker. (2020, October). Moral Economies of Open Data Platforms and Smart Cities. Paper presented at AoIR 2020: The $21^{\text {th }}$ Annual Conference of the Association of Internet Researchers. Virtual Event: AolR. Retrieved from http://spir.aoir.org. 
platform economies, and benefit from what Terranova $(2014,46)$ terms the "free labor" of those wishing to improve their communities.

Recent research has shown that the deployment of moral sentiments performs important social and political functions. Fassin $(2012,1)$ argued that "[m]oral sentiments have become an essential force in contemporary politics" to draw attention to the ways values and norms advance particular social and political agenda. Further to this point, Burns (2019) has shown that consumers' altruistic feelings of aid and assistance compel many private businesses' accumulation strategies, particularly in the context of technology development, and Taylor (2016) shows that this imperative can drive datathon themes and data sources. Together, these are comprise what Dourish and Satchell (2011) call a "moral economy", or the production, circulation, defense, and contestation of norms, values, and sentiments. In this, Dourish and Satchell draw on Scott's (1976) and Thompson's (1971) arguments that "peasants" leverage moral values to secure economic well-being that is regularly lost in the marketplace move from "fair price" to "free markets"; in other words, moral values underwrite economic activity.

In this presentation, we argue that hackathons, datathons, and open data platforms are constituted through moral economies that are entangled within technoscientific capitalist accumulation practices and logics. These moral economies are key ways in which digital labor is procured, and represent a core component of what for Boltanski and Chiapello (2018) constitutes the "new spirit of capitalism". To substantiate our argument, we draw on an ongoing long-term (4 years) ethnography into Calgary, Alberta's open data ecosystem. Our methodology consists of a hybrid between database ethnography (Schuurman 2008) and the extended case method (Burawoy 1998).

We show that open data platforms enroll the unremunerated labor of a range of stakeholders who comply due to the seeming altruism of such programs. We focus primarily on three contexts: a local wearables research project funneling into Calgary's open data platform, a plethora of citywide civic hacking organizations, and the broad category of city platforms like Nextdoor. The practices enacted in these contexts often ultimately advance neoliberal-if not fully private-logics, but always contribute to institutions sitting uncomfortably alongside the deleterious effects of privatized urban space. Put plainly, here we elucidate the ways in which moral economies of smart cities and municipal open data platforms have variegated impacts across different social groups and urban spaces. This reconfiguration of digital labor practices raises pressing concerns for the politics of claiming and remaking hybrid digital-urban forms of representation and belonging. We conclude by politicizing the fissures of these moral economies, to identify the new political strategies that they necessitate.

\section{References}

Barns, S. 2016. Mine your data: Open data, digital strategies and entrepreneurial governance by code. Urban Geography 37(4): 554-571.

Beer, D. 2018. The data gaze: Capitalism, power and perception. Thousand Oaks, CA: Sage. 
Benkler, Y. 2006. The wealth of networks: How social production transforms markets and freedom. New Haven, CT: Yale University Press.

Boltanski, L., and E. Chiapello. 2018. The new spirit of capitalism. Brooklyn, New York: Verso Books.

Burawoy, M. 1998. The extended case method. Sociological Theory 16(1): 4-33.

Burns, R. 2019. New frontiers of philanthro-capitalism: Digital technologies and humanitarianism. Antipode 51(4): 1101-1122.

Burns, R., and M. J. Andrucki. 2020. Smart cities: Who cares? Environment \& Planning A. OnlineFirst.

Burns, R., and G. Wark. 2019. Where's the database in digital ethnography? Exploring database ethnography for open data research. Qualitative Research. OnlineFirst.

Civil Beat. 2013. Will open data make Honolulu gov't more transparent? Honolulu Civil Beat. http://www.civilbeat.org/2013/11/will-open-data-make-honolulu-govt-moretransparent/ (last accessed 19 May 2017).

Couldry, N., and U. A. Mejias. 2019. The costs of connection: How data is colonizing human life and appropriating it for capitalism. Stanford, CA: Stanford University Press.

Dourish, P., and C. Satchell. 2011. The moral economy of social media. In From social butterfly to engaged citizen, eds. M. Foth, L. Forlano, C. Satchell, and M. Gibbs, 21-37. Cambridge, MA: MIT Press.

Fassin, D. 2012. Humanitarian reason: A moral history of the present. Berkeley, CA: University of California Press.

Graham, M., I. Hjorth, and V. Lehdonvirta. 2017. Digital labour and development: Impacts of global digital labour platforms and the gig economy on worker livelihoods. Transfer: European Review of Labour and Research 23(2): 135-162.

Irani, L. 2015. Hackathons and the making of entrepreneurial citizenship. Science, Technology \& Human Values 40(5): 799-824.

Kitchin, R. 2014. The data revolution: Big data, open data, data infrastructures and their consequences. Thousand Oaks, CA: Sage Publications.

Schrock, A. R. 2016. Civic hacking as data activism and advocacy: A history from publicity to open government data. New Media \& Society 18(4): 581-599.

Schuurman, N. 2008. Database ethnographies using social science methodologies to enhance data analysis and interpretation. Geography Compass 2(5): 1529-1548. 
Scott, J. C. 1976. The moral economy of the peasant: Rebellion and subsistence in Southeast Asia. New Haven, CT: Yale University Press.

Srnicek, N. 2017. Platform capitalism. Malden, MA: Polity Press.

Taylor, L. 2016. The ethics of big data as a public good: Which public? Whose good? Philosophical Transactions of the Royal Society A 374: 1-13.

Terranova, T. 2014. Free labor. In Digital labor: The Internet as playground and factory, ed. T. Scholz, 33-57. New York: Routledge.

Thompson, E. 1971. The moral economy of the English crowd in the eighteenth century. Past \& Present 50: 76-136.

Yu, H., and D. G. Robinson. 2011. The new ambiguity of open government. UCLA Law Review Discourse 59: 178-209. 